\title{
The potential protective effect of propolis on experimentally induced hepatitis in adult male albino rats. Histological and immunohistochemical study
}

\author{
Abeer M. El-Mahalaway ${ }^{1 *}$, Amal A. Selim² and Faiza Abdul Razzak Mahboub² \\ *Correspondence: abeerelmahalaway@yahoo.com

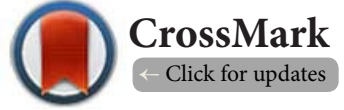 \\ 'Department of Histology and Cell Biology, Benha Faculty of Medicine, Benha University, Egypt. \\ ${ }^{2}$ Department of Biology, Faculty of Applied Sciences, Umm Al-Qura University, Makkah, Kingdom of Saudi Arabia.
}

\begin{abstract}
Background: In Egypt, liver diseases are one of the most prominent killers especially hepatitis virus infection, fibrosis and cirrhosis. Hepatitis has a serious health effects and alter the functions of the liver. D-galactosamine (D-GalN) and Lipopolysaccharide (LPS) induced hepatitis in rats are closely resembling human viral hepatitis. Propolis is honey bee product with a wide range of beneficial therapeutic effects. Objective: To evaluate the possible protective effect of propolis on experimentally induced hepatitis in adult male albino rats.

Materials and methods: Forty adult male rats included and divided equally into 4 groups (10 rats each). group I (control group), group II (Propolis group): The rats received daily oral dose of the propolis (200mg/Kg) by gastric tube for 2 weeks, group III (Hepatitis model group): The rats received single intraperitoneally injection of D-GalN and LPS (300 mg/kg and $30 \mu \mathrm{g} / \mathrm{kg}) 18$ hours before the end of experiment, group IV (Propolis and hepatitis model group): The rats received daily oral dose of propolis for 2 weeks and D-GalN and LPS 18 hours before the end of experiment. Liver specimens were taken and processed for histological and immunohistochemical study.

Results: Group III showed signs of degeneration and necrosis as some swollen hepatocytes had finely granular cytoplasm, other hepatocytes had small hyperchromatic or karyolytic nuclei. Dilated congested, proliferation of endothelial cells of central vein were seen and its wall showed inflammatory cells. There were apparent increase of collagen fibers, significant increase of anti-proliferating cell nuclear antigen (PCNA) positive nuclei among hepatocytes and strong immunoreaction for anti-Transforming growth factor (TGF- $\left.\beta_{1}\right)$ in the wall of portal vein. Group IV showed improvement of histological and immunohistochemical changes described before.
\end{abstract}

Conclusion: Propolis has potential protective effect against D-GalN/LPS induced hepatotoxicity in rats as it has antioxidant, anti-inflammatory and antiapoptotic activities.

Keywords: Acute hepatitis, D-galactosamine, lipopolysaccharide, immunohistochemistery, propolis

\section{Introduction}

The liver is a vital organ that plays a key role in the detoxification of exogenous and endogenous substances. It also performs a wide range of metabolic activities required for homeostasis, nutrition and immune defense. A variety of pathological factors including viral hepatitis (especially hepatitis $B$ and $C$ ), alcohol and drug abuse, metabolic diseases, autoimmune diseases and congenital abnormalities can cause hepatic injury. Liver fibrosis is the final stage of all chronic hepatic disease. Hepatic stellate cells (HSCs) play a principal role in liver fibrosis. It is a well-known fact that fibrosis has lots of important complications such as portal hypertension, hepatocellular carcinoma, hepatic encephalopathy, spontaneous bacterial peritonitis and hepatorenal syndrome $[\mathbf{1}, \mathbf{2}]$.

Hepatitis is a major public health problem worldwide, responsible for considerable morbidity and mortality from liver disease. Common causes of hepatitis include viral infection, side effects of certain prescription drugs and overdoses of the 
over-counter drugs [3].

Among the numerous models of experimental hepatitis, Lipopolysaccharide (LPS)/D-galactosamine (D-GaIN) are a well-established hepatotoxicant, inducing liver damage which closely resembling to human viral hepatitis in its morphological and functional features [4].

LPS is a toxic component of the cell walls of gram-negative bacteria and is widely present in the digestive tracts of humans and animals [5]. D-GalN is an amino sugar selectively metabolized by hepatocytes [6]. The toxicity of D-Gal N is mainly related to depletion of uridine pools that are associated with limited ribonucleic acid (RNA), glycogen and protein synthesis, thus altering hepatocellular function [4].

Currently, hepatoprotective drugs are inadequate, so far no therapy has successfully prevented the progression of hepatic disease; even though newly developed drugs have been used to treat chronic liver disorders, these drugs have often have side effects. Therefore, a special interest has been directed to the use of dietary antioxidants of natural products in the treatment of such disorders and may have a significant role in maintaining health $[7,8]$.

Propolis is considered as one of the most promising natural products has therapeutic and preventive actions. It contains more than 300 compounds from different groups. It contains mostly a mixture of polyphenols, flavonoids (major ingredients). Propolis can be used for treatment of cardiovascular, blood system, respiratory disorders, cancer, digestive tract disorders and dermatological disorders [9-11].

Propolis exhibits a wide spectrum of pharmacological properties such as antioxidant, anti-inflammatory, antibacterial, antiviral, anti-ulcerous, anticarcinogenic properties and immune system support $[10,12]$.

The aim of this study was to evaluate the possible protective effect of propolis on experimental induced hepatitis in adult male albino rats.

\section{Materials and methods}

In this study, 40 adult male rats of average weight 150-250 $\mathrm{g}$ were used The animals obtained from the animal house, Moshtohor faculty of Veterinary Medicine, Benha University, Moshtohor city, Egypt. Animals were housed in the animal laboratory at the medical research center of Benha faculty of medicine. Strict care and cleaning measures were utilized to keep the animal in a normal healthy state, the animals were kept in animal cages under the prevailing atmospheric conditions and also were fed to standard basal diet and liberal supply of tap water. All ethical protocols for animal treatment were followed and were supervised by the animal facilities. The experimental protocol was approved by the Ethical Committee of Benha faculty of medicine.

\section{Used drugs}

LPS (lipopolysaccharide from Escherichia coli, O55:B5), and $\mathrm{N}$-acetyl D-GalN, were purchased from Sigma-Aldrich Company-
Saint Louis, Missouri, USA. Propolis was purchased from a beekeeper. It was dissolved in 1\% gum acacia, forming an aqueous solution.

\section{Diagnostic kits}

1. For the determination of alanine aminotransferase (ALT), aspartate aminotransferase (AST), and bilirubin using kits were purchased from Bio diagnostic Co, Cairo, Egypt.

2. For the determination of Tumour necrosis factor $a$ (TNF-a): using the a commercially available enzyme-linked immunosorbent assay (ELISA) Ray Bio Rat TNF-a kit (Catalogue number ELR-TNF-a 001, Ray Biotech Inc., 3607 Parkway Lane, Suite 100, Norcross GA 30092, USA).

\section{Experimental procedure}

Rats were divided into 4 groups, included 10 rats for each as follows

Group I (Control group)

The 5 rats received intraperitoneally injection of phosphatebuffered saline as vehicle for D-GaIN and LPS. They were sacrificed at the same time as the corresponding experimental groups. The other 5 rats received $0.5 \mathrm{ml}$ gum acacia dissolved in distilled water as vehicle for propolis. They were sacrificed at the same time as the corresponding experimental groups.

\section{Group II (Propolis group)}

Rats received an aqueous suspension of propolis $200 \mathrm{mg} / \mathrm{kg}$ orally by gastric tube daily for 2 weeks [7].

\section{Group III (Hepatitis model group)}

Rats received single intraperitoneally injection of D-GalN and LPS ( $300 \mathrm{mg} / \mathrm{kg}$ body weight and $30 \mu \mathrm{g} / \mathrm{kg}$ body weight) dissolved in phosphate-buffered saline $18 \mathrm{hrs}$ before the end of experiment [8].

\section{Group IV (Propolis and hepatitis model group)}

Rats received an aqueous suspension of propolis $200 \mathrm{mg} / \mathrm{kg}$ orally by gastric tube daily for 2 weeks and received single intraperitoneally injection of D-GalN and LPS $(300 \mathrm{mg} / \mathrm{kg}$ body weight and $30 \mu \mathrm{g} / \mathrm{kg}$ body weight) dissolved in phosphatebuffered saline $18 \mathrm{hrs}$ before the end of experiment.

The blood was drained from the tail vein by using capillary tubes immediately before the end of the experiment into Eppendorf tubes containing heparin $(20 \mathrm{ml}, 200 \mathrm{IU} / \mathrm{ml})$. The plasma was separated by centrifugation ( $5000 \mathrm{rpm}$ for $5 \mathrm{~min}$ ) and used for biochemical analysis.

\section{Biochemical measurements Liver function tests}

Plasma alanine aminotransferase (ALT), aspartate aminotransferase (AST) [13], total bilirubin [14], albumin [15] were measured.

Tumor necrosis factor $\alpha$ (TNF- $\alpha$ )

Quantitive determination of serum (TNF-a) a hepatic proin- 
flammatory cytokine was carried by using the a commercially available enzyme-linked immunosorbent assay [16].

At the end of the experiment, the rats were scarified by cervical decapitation. Specimens of liver were taken. Paraffin sections of about 5-6 $\mu \mathrm{m}$ were prepared and stained with hematoxylin and eosin (H\&E) to verify the histological details \& Masson's trichrome to demonstrate the collagen fibers [17].

\section{Imunohistochemistery study}

1. Imunohistochemical staining for detection of antiproliferating cell nuclear antigen (PCNA); the primary monoclonal antibody used was anti-PCNA IgG antibody (Santa Cruz Biotechnology Inc., Santa Cruz, CA, USA). The cellular site of the reaction was nuclear and brown color.

2. Imunohistochemical staining for detection of antiTransforming growth factor (TGF- $\beta 1$ ); the primary monoclonal antibody used was TGF- $\beta 1 \mathrm{lgG}$ antibody (Biogen Inc., Cambridge, Massachusetts, USA). The cellular site of the reaction was cytoplasmic and brown color. Imunohistochemical study was conducted using the avidinbiotin peroxidase method. Briefly, sections of about $5 \mu \mathrm{m}$ were deparaffinized, rehydrated, rinsed in tap water, and embedded in $3 \% \mathrm{H}_{2} \mathrm{O}_{2}$ for 10 min to block endogenous peroxidase. The sections were treated initially with $2 \%$ trypsin at $37^{\circ} \mathrm{C}$ for $10 \mathrm{~min}$ in order to increase the sensitivity of the immunoperoxidase staining method. Sections were immersed in an antigen retrieval solution $(10 \mathrm{mmol} / \mathrm{l}$ sodium citrate buffer, $\mathrm{pH}$ 6) and subjected to heat-induced antigen retrieval for 20 min in a microwave. Nonspecific protein binding was blocked by a blocking solution (phosphate buffer solution (PBS) and $10 \%$ normal goat serum). The slides were incubated for 30 min with the diluted primary antibody using PBS. Drops of streptavidin peroxidase were added to the slide, left for 20 $\mathrm{min}$ and then washed with PBS for $5 \mathrm{~min}$. Diaminobenzidine (Dakopatts, Glostrup, Denmark) was added to slides as a chromogen, after which the slides were washed with distilled water. Finally, the sections were counterstained with hematoxylin, dehydrated, rendered transparent with xylene, mounted and observed under a light microscope. For the negative control the specific primary antibody was replaced by phosphate-buffered saline.

\section{Morphometric study}

The mean area percentage (\%) of PCNA and TGF- $\beta 1$ reaction were quantified in 10 images for each group using Image-Pro Plus program version 6.0 (Media Cybernetics Inc., Bethesda, Maryland, USA). Mean area percentage of PCNA reaction and TGF- $\beta 1$ in group IV (Propolis and hepatitis model group) compared with group III (Hepatitis model group) using the $\mathrm{t}$-test, with $\mathrm{P}<0.05$ as the level of statistical significance.

Statistical analysis

Statistical analyses were carried out using IBM SPSS statistics software for Windows, Version 20 (IBM Corp., Armonk, NY, USA).
All data were expressed as mean $\pm S D$. The significance of dif ferences between mean values was analyzed by using the t-test, with $\mathrm{P}<0.05$ as the level of statistical significance.

\section{Result}

\section{Biochemical results}

As shown in Table 1. In group III compared to control group, the liver injury markers of ALT, AST, total Bilirubin and TNF-a were very highly significant increase $(p<0.001)$, but albumin was very highly significant decrease $(p<0.001)$. In group IV compared to group III, ALT was significant decrease $(p<0.05)$, AST was very highly significant decrease $(p<0.001)$, total Bilirubin was highly significant decrease $(p<0.01)$ and TNF- $a$ was very highly significant decrease $(p<0.001)$, but albumin was highly significant increase $(p<0.01)$.

Table 1. Showing changes in liver function tests and TNF- $\alpha$ in all experimental groups.

\begin{tabular}{lllll}
\hline & Group I & Group II & Group III & Group IV \\
\hline $\begin{array}{l}\text { Serum } \\
\text { AlT (U/L) }\end{array}$ & $31.36 \pm 2.6$ & $33.40 \pm 8.2$ & $98.27 \pm 5.4^{*}$ & $61.74 \pm 4.8^{\mathrm{a}}$ \\
$\begin{array}{l}\text { Serum } \\
\text { AST (U/L) }\end{array}$ & $80.18 \pm 4.5$ & $85.50 \pm 18.9$ & $250.50 \pm 18.9^{\star}$ & $180.90 \pm 9.5^{\mathrm{c}}$ \\
$\begin{array}{l}\text { Albumin } \\
\text { (g/dl) }\end{array}$ & $4.52 \pm 0.25$ & $4.25 \pm 0.15$ & $1.99 \pm 0.14^{*}$ & $2.62 \pm 0.26^{\mathrm{b}}$ \\
$\begin{array}{l}\text { Total } \\
\text { bilirubin } \\
(\mathrm{mg} / \mathrm{dl})\end{array}$ & $0.70 \pm 0.03$ & $0.75 \pm 0.02$ & $1.55 \pm 0.14^{*}$ & $0.92 \pm 0.04^{\mathrm{b}}$ \\
$\begin{array}{l}\mathrm{TNF}-\alpha \\
(\mathrm{Pg} / \mathrm{ml})\end{array}$ & $21.5 \pm 2.55$ & $22.6 \pm 2.61$ & $130.7 \pm 0.96^{*}$ & $45.14 \pm 4.81^{\mathrm{c}}$ \\
\hline
\end{tabular}

Values are presented as mean \pm SD. P values: ${ }^{*}<0.001$ (Group III compared with control group I). P values: $\mathrm{a}<0.05, \mathrm{~b}<0.01, \mathrm{c}<0.001$ (Group IV compared with group III).

\section{Histological results \\ Haematoxylin and eosin \\ Group I (Control group)}

The liver sections of the group I showed cords of normal hepatocytes radiating from central vein. Hepatocytes are polyhedral in shape with central vesicular nuclei with prominent nucleoli and acidophilic cytoplasm. Some hepatocytes may be binucleated. Slit like spaces lined by endothelial cells and kupffer cells representing blood sinusoid were seen between the cords of hepatocytes (Figure 1A). The portal tract contained a branch of portal vein, a branch of hepatic artery and a branch of bile duct (Figure 1B).

\section{Group II (Propolis group)}

No histological changes were observed in the group II as compared to that of the control group.

\section{Group III (Hepatitis model group)}

Showed signs of degeneration and necrosis as some swollen 


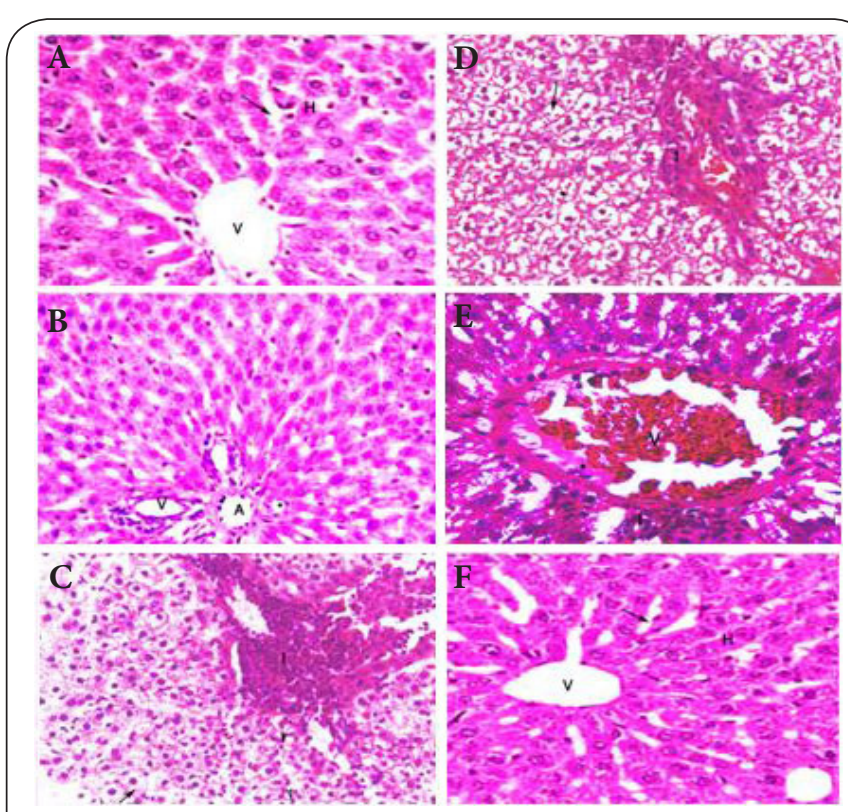

Figure 1. Photomicrograph of liver sections stained with hematoxylin and eosin.

(A) Liver section from group I showing cords of normal hepatocytes $(\mathrm{H})$ radiating from central vein $(\mathrm{V})$. Hepatocytes are polyhedral in shape with central vesicular nuclei and acidophilic cytoplasm. Slit like spaces lined by endothelial cells representing blood sinusoid are seen between the cords of hepatocytes $(\uparrow)$ [H\&E X400]. (B) Liver section from group I showing portal tract with portal vein $(\mathrm{V})$, hepatic artery (A) and bile duct $\left(^{*}\right)$ [H\&E X400]. (C) Liver section from group III showing monocellular infiltration (I). Some swollen hepatocytes show finely granular cytoplasm $(\uparrow)$. The hepatocytes show small hyperchromatic nuclei (arrow head $\wedge$ ). Notice collapse of sinusoids between hepatocytes. [H\&E X400]. (D) Liver section from group III showing empty hepatocytes that contain wisp of cytoplasmic remnants $\left({ }^{*}\right)$. The nuclei of some hepatocytes show karyolytic changes $(\uparrow)$ and the wall of blood vessel is thickened by inflammatory cells (I). [H\&E X400]. (E) Liver section from group III showing dilated congested central vein $(\mathrm{V})$. Notice swelling and proliferation of endothelial cells of central vein $\left({ }^{*}\right)$ and its wall show inflammatory cells (I). [H\&E X630]. (F) Liver section from group IV showing more or less normal hepatocytes $(\mathrm{H})$, central vein $(\mathrm{V})$ and blood sinusoids $(\uparrow)$. [H\&E X400].

hepatocytes had finely granular cytoplasm, other hepatocytes had small hyperchromatic nuclei. Monocellular infiltration and collapse of sinusoids between hepatocytes were seen (Figure 1C). Empty hepatocytes that contained wisp of cytoplasmic remnants were seen. The nuclei of some hepatocytes showed karyolytic changes and the wall of blood vessel was thickened by inflammatory cells (Figure 1D). Dilated congested central vein, swelling and proliferation of endothelial cells of central vein (central phlebitis) were seen and its wall showed inflammatory cells (Figure 1E).

\section{Group IV (Propolis and hepatitis model group)}

Showed preserved hepatic architecture as more or less normal hepatocytes, central vein and blood sinusoids were seen (Figure 1F).

\section{Masson's trichrome stain Group I (Control group)}

The liver sections of the group I showed little amount of collagen fibers around central vein and portal tract (Figures 2A and 2B).

\section{Group II (Propolis group)}

No detectable changes were observed in the distribution of collagen fibers in the liver of the group II as compared to that of the control group.

\section{Group III (Hepatitis model group)}

Showed apparent increase of collagen fibers around the central vein and portal tract and between cords of hepatocytes and blood sinusoids (Figures 2C and 2D).

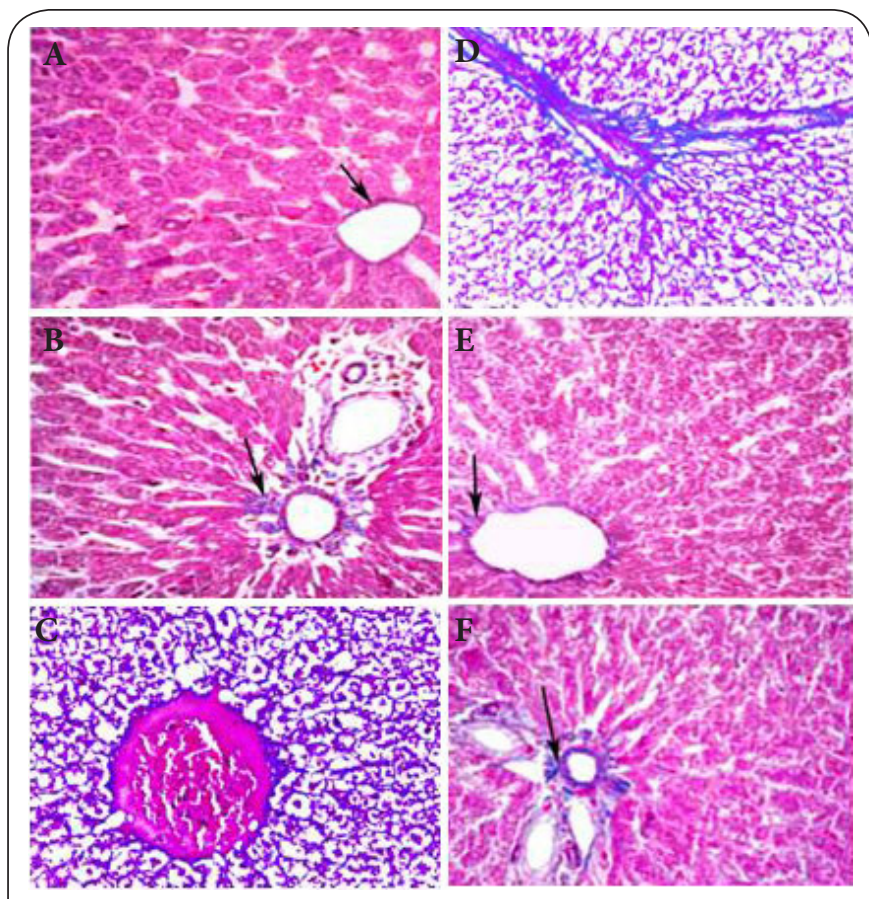

Figure 2. Photomicrograph of liver sections stained with masson trichrome.

(A) Liver section from group I showing few collagen fibers around central vein $(\uparrow)$. [Masson's Trichrome X400]. (B) Liver section from group I showing few collagen fibers around portal tract $(\uparrow)$. [Masson's Trichrome X400]. (C) Liver section from group III showing an apparent increase of collagen fibers around dilated congested central vein and blood sinusoids. [Masson's Trichrome X400]. (D) Liver section from group III showing an apparent increase of collagen fibers around portal area and blood sinusoids. [Masson's Trichrome X400]. (E) Liver section from group IV showing apparent scanty collagen fibers around central vein $(\uparrow)$. [Masson's Trichrome X400]. (F) Liver section from group IV showing apparent scanty collagen fibers in the portal area $(\uparrow)$. [Masson's Trichrome X400]. 


\section{Group IV (Propolis and hepatitis model group)}

Showed apparent scanty collagen fibers around the central vein and portal tract (Figures 2E and 2F).

Immunohisochemistery results

PCNA immunohistochemical stain

Group I (Control group)

The liver sections of the control group showed few brown PCNA positive nuclei among few hepatocytes (Figure 3A).

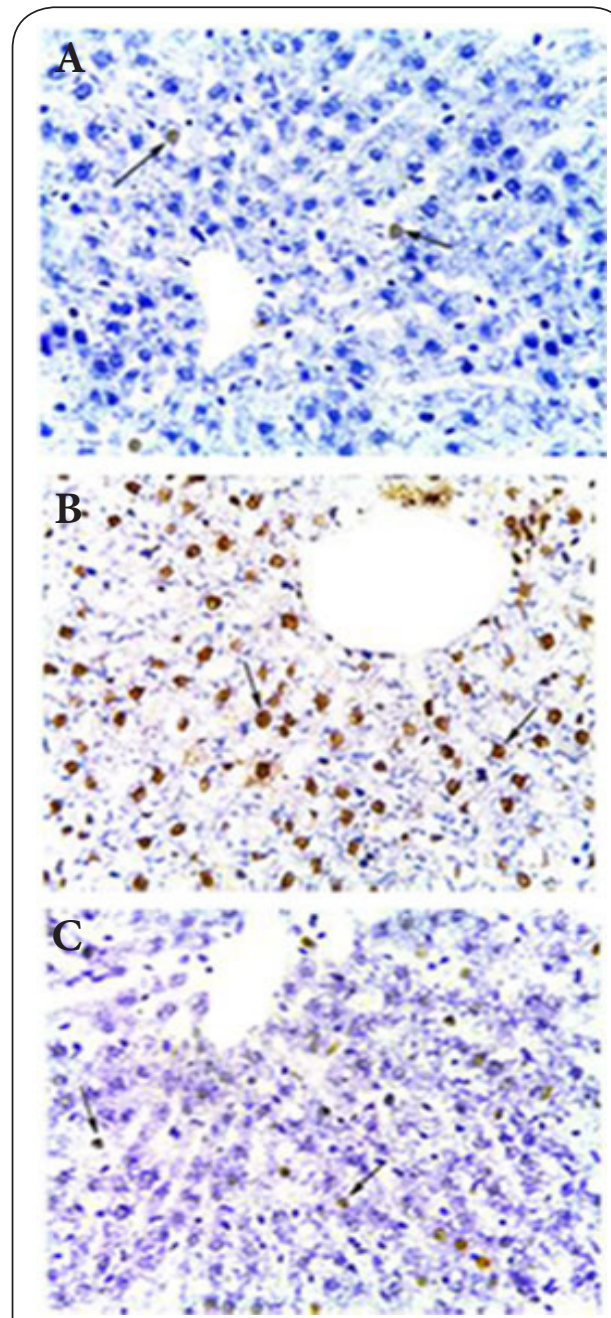

Figure 3. Photomicrograph of liver sections stained with anti-proliferating cell nuclear antigen (PCNA).

(A) Liver section from group I showing few brown PCNA positive nuclei among few hepatocytes $(\uparrow)$ [Immunostaining for PCNA X400]. (B) Liver section from group III showing increase the number of brown PCNA positive nuclei among hepatocytes ( $\uparrow$ [Immunostaining for PCNA X400]. (C) Liver section from group IV showing decrease the number of brown PCNA positive nuclei among hepatocytes $(\uparrow)$. [Immunostaining for PCNA X400].
Group II (Propolis group)

No detectable changes were observed to PCNA expression in the group II as compared to that of the control group.

\section{Group III (Hepatitis model group)}

Showed increase the number of brown PCNA positive nuclei among hepatocytes (Figure 3B).

\section{Group IV (Propolis and hepatitis model group)}

Showed decrease the number of brown PCNA positive nuclei among hepatocytes (Figure 3C).

\section{TGF- $\beta 1$ immunohistochemical stain Group I (Control group)}

The liver sections of the control group showed weak positive immunoreaction for TGF $\beta 1$ in the wall of central vein and blood sinusoids (Figure 4A).

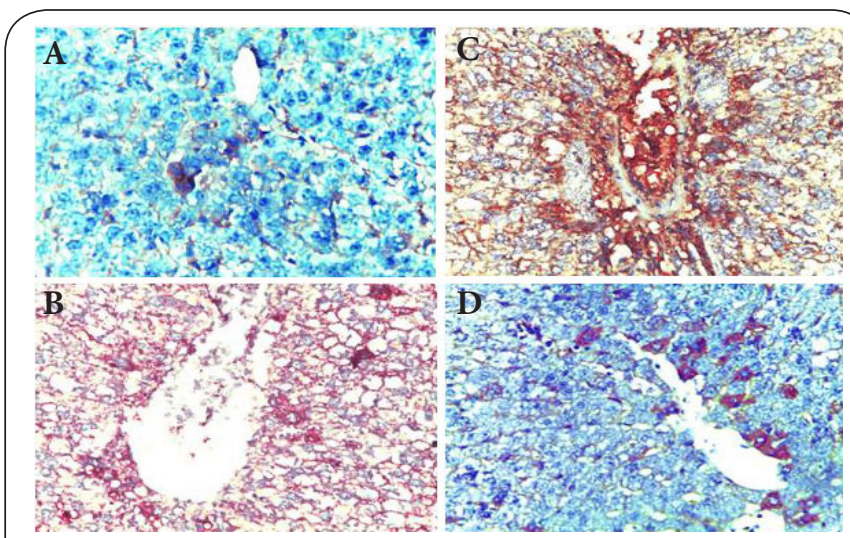

Figure 4. Photomicrograph of liver sections stained with transforming growth factor- $\beta 1$ (TGF- $\beta 1$ ).

(A) Liver section from group I showing weak positive immunoreaction for TGF- $\beta 1$ in the wall of central vein and blood sinusoids [Immunostaining for TGF- $\beta 1$ X400].

(B) Liver section from group III showing strong positive immunoreaction for TGF- $\beta 1$ in the wall of central vein and blood sinusoids [Immunostaining for TGF- $\beta 1$ X400]. (C) Liver section from group III strong positive immunoreaction for TGF- $\beta 1$ in the wall of portal vein and blood sinusoids. [Immunostaining for TGF- $\beta 1$ X400]. (D) Liver section from group IV showing moderate positive immunoreaction for TGF- $\beta 1$ in the wall of central vein and blood sinusoids. [Immunostaining for TGF- $\beta 1$ X400].

\section{Group II (Propolis group)}

No detectable changes were observed to TGF $\beta 1$ expression in the group II as compared to that of the control group.

\section{Group III (Hepatitis model group)}

Showed strong positive immunoreaction for TGF- $\beta 1$ in the wall of central vein, portal vein and blood sinusoids (Figures 4B and 4C).

Group IV (Propolis and hepatitis model group)

Showed moderate positive immunoreaction for TGF- $\beta 1$ in the 
wall of central vein and blood sinusoids (Figure 4D).

\section{Morphometric results}

The mean area \% of PCNA and TGF- $\beta 1$ reaction for studied experimental groups was represented in (Tables 2 and $\mathbf{3}$ ) and Histograms 1 and 2). There were significantly decreased $(\mathrm{P}<0.05)$ in PCNA and TGF- $\beta 1$ reaction in group IV compared with group III.

Table 2. Showing the mean area $\%$ and \pm SD of PCNA reaction in all experimental groups.

\begin{tabular}{lllll}
\hline & Group I & Group II & Group III & Group V \\
\hline Mean area \% & 0.06 & 0.07 & 3.63 & 0.18 \\
\pm SD & 0.027 & 0.03 & 0.484 & 0.096 \\
P value & -- & -- & -- & 0.000 \\
Significance & -- & -- & -- & $\mathrm{S}$ \\
\hline
\end{tabular}

SD: Standard deviation; S: Significant at $\mathrm{P}<0.05$

Group IV compared with group III.

Table 3. Showing the mean area $\%$ and \pm SD of TGF- $\beta 1$ reaction in all experimental groups.

\begin{tabular}{lllll}
\hline & Group I & Group II & Group III & Group V \\
\hline Mean area \% & 2.16 & 2.02 & 21.90 & 3.14 \\
\pm SD & 0.161 & 0.141 & 0.650 & 0.765 \\
P value & -- & -- & -- & 0.000 \\
Significance & -- & -- & -- & $\mathrm{S}$ \\
\hline
\end{tabular}

SD: Standard deviation; S: Significant at $\mathrm{P}<0.05$

Group IV compared with group III.

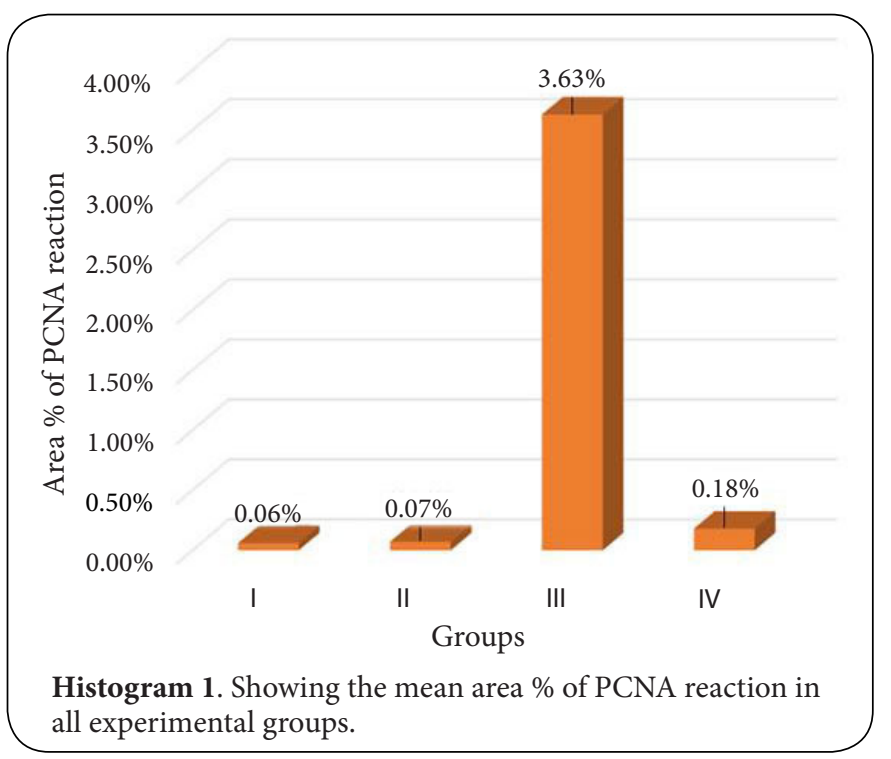

\section{Discussion}

Hepatitis remains as a clinical challenge and a problem of

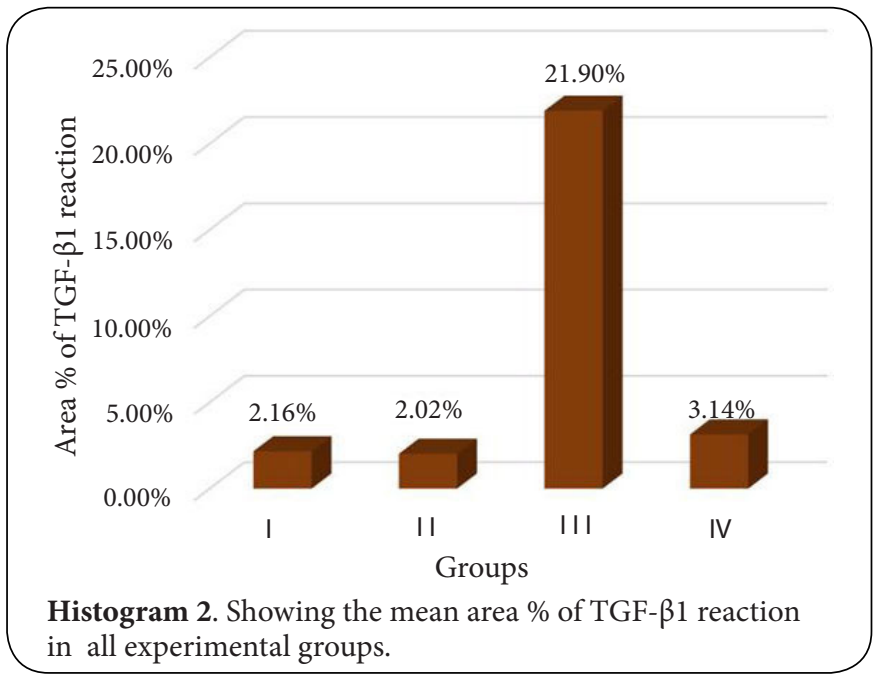

great importance in the worldwide today and affect a great number of population especially in Egypt [18].

In the present study our group III revealed a very highly significant increase of AST, ALT, total bilirubin and TNF-a but there was a very highly significant decrease of albumin as compared to control group.

Serum ALT and AST a cytoplasmic enzymes were released into circulation after cellular damage in acute hepatoxicity and were considered the most sensitive markers used in the diagnosis of hepatic damage [19].

Our results were in agreement with the findings of some investigators who reported that a liver damage induced by D-GalN/LPS reflected the disturbances of liver cell metabolism which leads to characteristic changes in the liver serum enzymes and albumin $[\mathbf{3 , 4 , 1 8 , 2 0 ]}$.

Serum bilirubin was considered as an index for the assessment of hepatic function and any abnormal increase indicates hepatobiliary disease [21].

D-galactosamine (D-GaIN) together with lipopolysaccharide (LPS) can lead to pronounced secretion of pro-inflammatory cytokine such as TNF-a by Kupffer, stellate and sinusoidal endothelial cells which had been shown to be early and important mediators of liver injury and hepatic necrosis $[3,22]$. Some authors clarified that the D-GaIN/LPS induced hepatocyte apoptotic changes and enhance the expression of cytokines TNF-a $[6,18]$.

The histological examination of liver sections of group III of the present study revealed signs of degeneration and necrosis such as some swollen hepatocytes had finely granular cytoplasm, other hepatocytes had small hyperchromatic nuclei or karyolytic changes. Monocellular infiltration and collapse of sinusoids between hepatocytes were seen. Empty hepatocytes that contained wisp of cytoplasmic remnants were seen. The wall of blood vessel was thickened by inflammatory cells. Central vein was dilated and congested and its wall infiltrated by inflammatory cells. Swelling and proliferation of endothelial cells of central vein (central phlebitis) were seen. 
These result were in agreement with previous studies indicated that during D-GaIN/LPS induced hepatitis, there were severe hepatocellular degeneration, necrosis and mononuclear cellular infiltration $[\mathbf{2 0}, \mathbf{2 3}, \mathbf{2 4}]$.

Some authors clarified that the D-GaIN/LPS induced marked cellular infiltration, is due to ROS production that indirectly regulate chemokine receptor expression and promote cytokine IL-6, IL-8 and TNF-a which are key modulators of inflammatory response [4].

Some investigators reported that central phlebitis characterized by swelling and proliferation of endothelial cells of central vein [25].

The release of aminotransferases by the damaged hepatocytes was strongly support the previous histological observations.

An apparent increase in collagen fibers around the central vein and the portal areas was seen in the present study. This was supported with strong positive immunoreaction for TGF- $\beta 1$ in the wall of central vein, portal vein and blood sinusoids.

Our results were in accordance with other researchers who stated the expression of TGF- $\beta 1$ could be correlated with the degree of liver damage to cirrhosis in chronic viral hepatitis [26]. Liver fibrosis, an early stage of cirrhosis, was a common consequence of chronic injury from many causes as infection and toxic drugs and characterized by the accumulation of extracellular matrix (ECM) proteins which; due to imbalance in their production, deposition, and breakdown. Prolonged liver injury result in hepatocytes damage, which triggers activation of hepatic stellate cells (HSCs). TGF- $\beta 1$ was produced by HSCs and Kupffer cells and was believed to be involved in the synthesis and deposition of extracellular matrix components like fibronectin, collagens type I, III, and IV. TGF- $\beta 1$ had a dual impact on the progression of liver disease by promoting fibrogenesis and inducing hepatocytes apoptosis [27-29].

Liver fibrosis was caused by a combination of multiple mechanisms, such as acute and chronic hepatocyte damage, recruitment and activation of inflammatory cells as macrophages, eosinophil and neutrophils, release of inflammatory and fibrogenic cytokines, production of reactive oxygen species; activation of hepatic stellate cells (HSCs), periportal or perivenular fibroblasts, circulating fibrocytes, and bone marrow cells that transdifferentiate into collagen producing myofibroblats [29-31].

Portal hypertension was a major complication of advanced liver cirrhosis. The main reason of portal hypertension was pathologically elevated intrahepatic resistance to portal blood flow due to fibrosis or cirrhosis caused by different chronic mainly inflammatory stimuli. The site of the increased resistance may be prehepatic (portal vein obstruction) or posthepatic (hepatic vein obstruction) [32].

An increase in the number of brown PCNA positive nuclei among hepatocytes were seen in group III of the present study. Proliferating cell nuclear antigen (PCNA) was a marker of cell proliferation.
PCNA found in cell nucleus and was directly involved in DNA replication. Its expression was increased at late G1 stage and early $S$ stage. Previous studies had demonstrated that PCNA labeling index increased sequentially from normal tissue through premalignant stage to carcinoma of various tumors [33,34].

Some investigators reported PCNA had been also found to induce apoptosis in cells subjected to oxidative stress [35].

Our findings were in accordance with those of previous studies who suggested that the ability of cell proliferation become stronger and this was closely related to malignant cell proliferation and carcinogenesis in livers of D-GalN/LPS treated rats [36-38].

In many liver disorders, inflammation, fibrosis and apoptosis are important pathogenic components, finally leading to acute liver failure [39].

Some researchers demonstrated that the mechanism of action of D-GalN/LPS induced hepatitis mediated through release of the oxidized products of oxidative stress such as reactive oxygen species (ROS) and different cytokines released by Kupffer cells (KC) of the liver such as tumor necrosis factor (TNF-a), Interleukin-1 (IL-1) and Interleukin-6 (IL-6). These ROS of oxidative stress were altering and damaging the cell compounds as protein and lipid as well as membranes and leading to increase lipid peroxidation and hepatic damage characterized by hepatocellular necrosis, inflammation and apoptosis $[4,5,22,40]$.

In the present study group IV revealed a marked improvement of biochemical parameter, histological changes of liver. Moreover, a decrease in the number of brown PCNA positive nuclei among hepatocytes and moderate positive immunoreaction for TGF- $\beta 1$ in the wall of portal vein and blood sinusoids.

These results are in agreement and confirming the findings of some researchers who reported the protective effect of propolis against hepatotoxicity as it contains higher content of total phenolic compounds $[7,9,41]$.

Some researchers reported that the protective effect of propolis was due to its antioxidant properties, as it acts as a free-radical scavenger and lipid peroxidation inhibitor. Further it was increasing the intracellular concentration of glutathione and superoxide anions and antioxidant enzymes [42]. Moreover propolis was improving the activity of hepatic microsomal drug metabolizing enzymes [10].

Propolis had potent anti-inflammatory and immunomodulatory agents which acted through inhibiting neutrophil infiltration, suppression of proinflammatory cytokines or mediators as tumor necrosis factor- $a$ and interleukins and stimulation of macrophages and thus influencing specific and nonspecific immune defense mechanisms $[11,43]$. Some researcher reported that propoils had been shown to ameliorate fibrosis due to its antioxidant properties [12]. Other investigators had reported that propolis might exert a modulatory effect on cytokine TGF- $\beta 1$ induced fibrosis [44]. Some 
investigators reported that the propolis had antiproliferative and anticarcinogenic activity $[34,45]$.

\section{Conclusion}

Acute D-GAIN/LPS induced hepatitis model caused an increase of oxidative stress and degenerative changes of liver. Propolis had a potential protective effect and preventing degenerative changes of liver caused by D-GAIN/LPS as it had antioxidant, anti-inflammatory enzyme and antiapoptotic activities. These results should provide a new insight in treating patients with acute hepatitis and thus the intake of propolis as supplement should be advised and might serve as clinically useful hepatoprotective natural product in future.

\section{Competing interests}

The authors declare that they have no competing interests. Authors' contribution

\begin{tabular}{|l|c|c|c|}
\hline Authors' contributions & AMEM & AAS & FARM \\
\hline Research concept and design & $\checkmark$ & -- & -- \\
\hline Collection and/or assembly of data & $\checkmark$ & $\checkmark$ & $\checkmark$ \\
\hline Data analysis and interpretation & $\checkmark$ & $\checkmark$ & $\checkmark$ \\
\hline Writing the article & $\checkmark$ & -- & -- \\
\hline Critical revision of the article & $\checkmark$ & $\checkmark$ & $\checkmark$ \\
\hline Final approval of article & $\checkmark$ & $\checkmark$ & $\checkmark$ \\
\hline Statistical analysis & -- & $\checkmark$ & -- \\
\hline
\end{tabular}

\section{Acknowledgement}

The authors thank all the staff members of Histology and Cell Biology Department in Benha Faculty of Medicine, Benha University, Egypt and professor Amany Elshawarby, head of Histology and Cell Biology Department, Ain Shams Faculty of Medicine, Cairo, Egypt for their cooperation and helpful comments during this work.

\section{Publication history}

Editors: Niki J. Agnantis, loannina University, Greece. Giuseppe Musumeci, University of Catania, Italy. Received: 18-Apr-2015 Final Revised: 17-May-2015 Accepted: 21-May-2015 Published: 28-May-2015

\section{References}

1. Abdel-Mohsen AF, Salama NM, Elgendy MS and Elsayed AM. Histological study on the effect of stem cells and hepatocyte growth factor on induced liver fibrosis in male albino rats. The Egyptian Journal of Histology. 2014; 37:615-628. | Article

2. Ahmed SK, Mohammed SA, Khalaf G and Fikry H. Role of Bone Marrow Mesenchymal Stem Cells in the Treatment of CCL4 Induced Liver Fibrosis in Albino Rats: A Histological and Immunohistochemical Study. Int J Stem Cells. 2014; 7:87-97. | Article | PubMed Abstract | PubMed Full Text

3. Jihan $\mathrm{H}$, Eman R, Safaa M, Dalia M and Fatma O. Green tea attenuates experimental hepatitis in context of oxidative stress. Journal of Applied Pharmaceutical Science. 2013; 3:124-128. | Pdf

4. Padmanabhan $P$ and Jangle $S N$. Hepatoprotective activity of herbal preparation (HP-4) against D-Galactosamine induced hepatotoxicity in mice. International Journal of Pharmaceutical Sciences and Drug Research. 2014; 6:31-37. I Pdf

5. Wang X, Zhang L, Wei Z, Zhang X, Gao Q, Ma Y, Liu X, Jiang Y and Guo C. The inhibitory action of PDCD4 in lipopolysaccharide/D-galactosamine- induced acute liver injury. Lab Invest. 2013; 93:291-302. | Article | PubMed

6. Wu YH, Hu SQ, Liu J, Cao HC, Xu W, Li YJ and Li LJ. Nature and mechanisms of hepatocyte apoptosis induced by D-galactosamine/ lipopolysaccharide challenge in mice. Int J Mol Med. 2014; 33:1498-506. | Article | PubMed Abstract | PubMed Full Text

7. Bhadauria M. Propolis prevents hepatorenal injury induced by chronic exposure to carbon tetrachloride. Evid Based Complement Alternat Med. 2012; 2012:235358. | Article | PubMed Abstract | PubMed Full Text

8. El-Meligy RM, Zain ME and Ahmed FA. Protective role of Cynanchum acutum $\mathrm{L}$. extracts on carbon tetrachloride-induced hepatotoxicity in rat. Int. J. Chem. Appl. Biol. Sci. 2014; 1:8-13. | Article

9. Saleh EM. Antioxidant effect of aqueous extract of propolis on hepatotoxicity induced by octylphenol in male rats. Acta Toxicol. Argent. 2012; 20:68-81. | Pdf

10. Mahmoud EF and Mahmoud MF. Evaluation of The effect of Propolis extract on the Tongue mucosa of an Induced toxic rabbit by Fenitrothion. Life Science Journal. 2013; 10:767-775. | Pdf

11. Nakamura T, Ohta Y, Ohashi K, Ikeno K, Watanabe R, Tokunaga K and Harada N. Protective Effect of Brazilian Propolis against Liver Damage with Cholestasis in Rats Treated with alpha-Naphthylisothiocyanate. Evid Based Complement Alternat Med. 2013; 2013:302720. | Article | PubMed Abstract | PubMed Full Text

12. Araujo MAR, Libério SA, Guerra RNM, Ribeiro MNS and Nascimento FRF. Mechanisms of action underlying the anti-inflammatory and immunomodulatory effects of propolis: a brief review. Braz. J. Pharmacognosy. 2012; 22:208-219. | Article

13. Reitman $S$ and Frankel $S$. A colorimetric method for the determination of serum glutamic oxalacetic and glutamic pyruvic transaminases. Am J Clin Pathol. 1957; 28:56-63. | PubMed

14. Walter $M$ and Gerade RW. An ultramicromethod for the determination of conjugated and total bilirubin in serum or plasma. Microchem. J. 1970; 15:231-233. | Aritcle

15. Doumas BT, Watson WA and Biggs HG. Albumin standards and the measurement of serum albumin with bromcresol green. Clin Chim Acta. 1971; 31:87-96. | Article | PubMed

16. Corti A, Fassina G, Marcucci F, Barbanti E and Cassani G. Oligomeric tumour necrosis factor alpha slowly converts into inactive forms at bioactive levels. Biochem J. 1992; 284:905-10. | Pdf | PubMed Abstract | PubMed Full Text

17. Bancroft JD and Layton C. The hematoxylin and eosin, connective and mesenchymal tissues with their stains In. S. Kim suvarna, Christopher Layton and John D. Bancroft editors. Bancrofts Theory and practice of histological techniques. th $^{\text {th }}$ ed. Churchill Livingstone: Philadelphia. 2013; 173-212.

18. Mahmoud $M$ and Hamdan D. Naringin and rutin prevent D-galactosamine-induced hepatic injury in rats via attenuation of the inflammatory cascade and oxidative stress. European Scientific Journal. 2013; 9:141-155. | Article

19. Heikal TM, Mossa AH, Abdel Rasoul MA and Marei GH. The ameliorating effects of green tea extract against cyromazine and chlorpyrifos induced liver toxicity in male rats. Asian. J. Pharm .Clin. Res. 2013; 6:48-55. I Pdf

20. Fyiad AA, Abd El-Kader MA and Abd El-Haleem AH. Modulatory effects of pomegranate juice on nucleic acids alterations and oxidative Stress in experimentaly hepatitis rats. Life Science Journal. 2012; 9:676-682. I Pdf

21. El-Alfy NZ, Ahmed HH, Mahmoud MF and Yahya SM. Regression of liver fibrosis by punica granatum peel extract in the experimental model. World Journal of Pharmacy and Pharmaceutical Sciences. 2014; 3:22-44. I Pdf

22. Kim SJ, Kim JK, Lee DU, Kwak JH and Lee SM. Genipin protects lipopolysaccharide-induced apoptotic liver damage in D-galactosaminesensitized mice. Eur J Pharmacol. 2010; 635:188-93. | Article | PubMed

23. Taye A, El-Moselhy MA, Hassan MK, Ibrahim HM and Mohammed AF. Hepatoprotective effect of pentoxifylline against $D$-galactosamineinduced hepatotoxicity in rats. Ann Hepatol. 2009; 8:364-70. | PubMed

24. Sheriff SA and Devaki T. Lycopene stabilizes lipoprotein levels during 
D-galactosamine/lipopolysaccharide induced hepatitis in experimental rats. Asian Pac J Trop Biomed. 2012; 2:975-80. I Article I PubMed Abstract I PubMed Full Text

25. Rubin R and Strayer DS. Rubin pathology:Clinicopathologic foundations of medicine. 5th ed. Baltimore, Md: Wolters Kluwer Health: Lippincott Williams \& Wilkins. 2008; 642-643.

26. Tache DE, Stanciulescu CE, Banita IM, Purcaru SO, Andrei AM, Comanescu $V$ and Pisoschi CG. Inducible nitric oxide synthase expression (iNOS) in chronic viral hepatitis and its correlation with liver fibrosis. Rom J Morphol Embryol. 2014; 55:539-43. I Pdf I PubMed

27. Bai T, Lian LH, Wu YL, Wan Y and Nan JX. Thymoquinone attenuates liver fibrosis via PI3K and TLR4 signaling pathways in activated hepatic stellate cells. Int Immunopharmacol. 2013; 15:275-81. | Article | PubMed

28. Noh DH, Lee EJ, Kim AY, Lee EM, Min CW, Kang KK, Lee MM, Kim SH, Sung SE, Hwang M, Yu DY and Jeong KS. Alcohol induced hepatic degeneration in a hepatitis $C$ virus core protein transgenic mouse model. Int J Mol Sci. 2014; 15:4126-41. | Article | PubMed Abstract | PubMed Full Text

29. Zhong L, Wang X, Wang S, Yang L, Gao H and Yang C. The anti-fibrotic effect of bone morphogenic protein-7(BMP-7) on liver fibrosis. Int J Med Sci. 2013; 10:441-50. | Article | PubMed Abstract | PubMed Full Text

30. Friedman SL. Evolving challenges in hepatic fibrosis. Nat Rev Gastroenterol Hepatol. 2010; 7:425-36. | Article | PubMed

31. Yao QY, Xu BL, Wang JY, Liu HC, Zhang SC and Tu CT. Inhibition by curcumin of multiple sites of the transforming growth factor-beta1 signalling pathway ameliorates the progression of liver fibrosis induced by carbon tetrachloride in rats. BMC Complement Altern Med. 2012; 12:156. | Article | PubMed Abstract | PubMed Full Text

32. Liedtke C, Luedde T, Sauerbruch T, Scholten D, Streetz K, Tacke F, Tolba $\mathrm{R}$, Trautwein $\mathrm{C}$, Trebicka $\mathrm{J}$ and Weiskirchen R. Experimental liver fibrosis research: update on animal models, legal issues and translational aspects. Fibrogenesis Tissue Repair. 2013; 6:19. | Article | PubMed Abstract | PubMed Full Text

33. Ismail MF, Ali DA, Fernando A, Abdraboh ME, Gaur RL, Ibrahim WM, Raj $\mathrm{MH}$ and Ouhtit $\mathrm{A}$. Chemoprevention of rat liver toxicity and carcinogenesis by Spirulina. Int J Biol Sci. 2009; 5:377-87. | Article | PubMed Abstract | PubMed Full Text

34. El-kott AF, Kandeel AA, Abed El-Aziz SF and Ribea HM. Effects of bee honey on PCNA and P53 expression in the rat hepatocarcinogenesis. International Journal of Cancer Research. 2012; 8:130-139. I Article

35. Hidaka M, Takagi Y, Takano TY and Sekiguchi M. PCNA-MutSalphamediated binding of MutLalpha to replicative DNA with mismatched bases to induce apoptosis in human cells. Nucleic Acids Res. 2005; 33:5703-12. | Article | PubMed Abstract | PubMed Full Text

36. Nafees S, Ali N, Rashid S, Hasan SK and Sultana S. Chemopreventive Effect of Bauhinia Purpurea Against Chemically Induced Hepatocarcinogenesis via Amelioration of Oxidative Damage, Cell Proliferation and Induction of Apoptosis in Wistar Rats. Toxicol Int. 2013; 20:117-25. | Article | PubMed Abstract | PubMed Full Text

37. Nitha A, Prabha SP, Ansil PN and Larha MS. Curative effect of woodfordia fruticosa kurz flowes on $\mathrm{N}$-nitrosodiethylamine induced hepatocellular carcinoma in rats. Int. J. Pharm. Pharm. Sci. 2014; 6:150-155. I Pdf

38. Shen T, Khor SC, Zhou F, Duan T, Xu YY, Zheng YF, Hsu S, J DES, Yang J, $\mathrm{Xu} \mathrm{LH}$ and Zhu XQ. Chemoprevention by lipid-soluble tea polyphenols in diethylnitrosamine/phenobarbital-induced hepatic pre-cancerous lesions. Anticancer Res. 2014; 34:683-93. | Article I PubMed

39. Aigner T. Apoptosis, necrosis, or whatever: how to find out what really happens? J Pathol. 2002; 198:1-4. | Article I PubMed

40. Lekic N, Cerny D, Horinek A, Provaznik Z, Martinek J and Farghali $H$. Differential oxidative stress responses to D-galactosaminelipopolysaccharide hepatotoxicity based on real time PCR analysis of selected oxidant/antioxidant and apoptotic gene expressions in rat. Physiol Res. 2011; 60:549-58. I Pdf I PubMed

41. Banskota AH, Tezuka Y, Adnyana IK, Midorikawa K, Matsushige K, Message D, Huertas AA and Kadota S. Cytotoxic, hepatoprotective and free radical scavenging effects of propolis from Brazil, Peru, the Netherlands and China. J Ethnopharmacol. 2000; 72:239-46. | Article | PubMed

42. Newairy AA and Abdou HM. Effect of propolis consumption on hepatotoxicity and brain damage in male rats exposed to chlorpyrifos. African Journal of Biotechnology. 2013; 12:5232-5243. I Pdf

43. Korish AA and Arafa MM. Propolis derivatives inhibit the systemic inflammatory response and protect hepatic and neuronal cells in acute septic shock. Braz J Infect Dis. 2011; 15:332-8. | Article | PubMed

44. de Moura SA, Ferreira MA, Andrade SP, Reis ML, Noviello Mde L and Cara DC. Brazilian green propolis inhibits inflammatory angiogenesis in a murine sponge model. Evid Based Complement Alternat Med. 2011; 2011:182703. | Article | PubMed Abstract | PubMed Full Text

45. El-Kott AF and Owayss AA. Protective Effects of Propolis Against the Amitraz Hepatotoxicity in Mice. Journal of Pharmacology and Toxicology. 2008; 3:402-408. | Article

Citation:

El-Mahalaway AM, Selim AA and Mahboub FAR.

The potential protective effect of propolis on experimentally induced hepatitis in adult male albino rats. Histological and immunohistochemical study. J Histol Histopathol. 2015; 2:14.

http://dx.doi.org/10.7243/2055-091X-2-14 